\title{
Infections in Cirrhotics: Types, Microbiological Spectrum and Risk Factors-5-Year Cohort Study
}

\author{
Iftikhar Haider Naqvi', Khalid Mahmood', Abu Talib', Mohammad Ubaid', \\ Aamer Mahmood ${ }^{2}$ \\ ${ }^{1}$ Department of Medicine, Civil Hospital Karachi, Dow University of Health Sciences, Karachi, Pakistan \\ ${ }^{2}$ Agha Khan University, Karachi, Pakistan \\ Email: drihnaqvi@gmail.com
}

Received 8 January 2014; revised 15 February 2014; accepted 23 February 2014

Copyright (C 2014 by authors and Scientific Research Publishing Inc.

This work is licensed under the Creative Commons Attribution International License (CC BY).

http://creativecommons.org/licenses/by/4.0/

(c) (i) Open Access

\begin{abstract}
Cirrhosis is an immunocompromised state that leads to various infections, with an estimated $30 \%$ mortality. Pakistan already has a high morbidity and mortality related to complications of cirrhosis. Where the data on infection among cirrhotics is scanty, this study aimed to determine the frequency, microbiological spectrum and various risk factors of infections in cirrhosis of liver. This is a prospective cohort study conducted at a tertiary care hospital. The microbiological spectrum and frequency of infections was determined in cirrhotics. Various risk factors for infection among cirrhotics were evaluated like upper gastrointestinal bleed, use of proton pump inhibitors, malnutrition and severity of cirrhosis. Out of eleven hundred and forty-one patients with cirrhosis of liver, four hundred and ninety $(42.94 \%)$ patients had infections. All kinds of infections like peritoneal, respiratory, urinary tract and skin were present in cirrhosis of liver where ascitic fluid infections (AFI) were the commonest i.e. $\mathbf{4 4 . 8 9 \%}$. The risk factors for bacterial infections among patients with cirrhosis of liver were upper gastrointestinal bleeding (odd ratio $=4.57, p=0.0001$ ), use of proton pump inhibitors (odd ratio $=2.57, \mathrm{p}=\mathbf{0 . 0 0 0 1}$ ), degree of malnutrition (odd ratio $=$ $10.34, p=0.0001$ ) and severity of cirrhosis (odd ratio $=12.99, p=0.000$ ). All types of infections occurred with varying frequency in cirrhosis of liver. Upper gastrointestinal bleeding, severity of cirrhosis, use of high dose proton pump inhibitors and severe malnutrition are important risk factors for infections among cirrhotics.
\end{abstract}

\section{Keywords}

Liver Cirrhosis; Proton Pump Inhibitors; Ascites; Bacterial Infections 


\section{Introduction}

Cirrhosis is an immunocompromised state that leads to a variety of infections, which in turn are responsible for an anticipated 30\% mortality [1]. The poor outcome has been coupled with bacterial infections for painstaking and recurring complications of cirrhosis [2]. Despite of contemporary advancement in the management of cirrhosis and its complications, infections still account a 4-fold increase in mortality [3]. Frequency of infections is higher in decompensated cirrhosis than in compensated disease. Once infection develops, it may ensue other complications like renal failure, encephalopathy and shock which adversely influence the survival. According to some recent prospective data 32\% - 34\% of cirrhosis either already have bacterial infection at admission or develop one during hospitalization [4]. Infections are even more pronounced and common at an estimated rate of $45 \%$ in patients with gastrointestinal haemorrhage, where these infections are allied with failure to manage bleeding and early rebleeding from varices [5]-[9]. The higher rate of infections among cirrhotics is in jagged distinction with the $5 \%-7 \%$ rate of overall infection in general population, endorsing the idea of cirrhosis to be an acquired state of immunodeficiency [1].

The significantly higher mortality with the occurrence of infection in cirrhosis is independently allied to the severity of liver disease [4]. The hospital related deaths in cirrhotics with infection is almost greater than $15 \%$, which is around more than double than those without infections. Notably, $30 \%-50 \%$ of deaths are a direct result of infections in cirrhosis [10].

Bacterial infections are enhanced by several factors like severity of liver disease, degree of malnutrition, upper gastro-intestinal hemorrhage, damaged mucocutaneous barrier, associated comorbids like (diabetes mellitus, malignancy), and invasive procedures [11] [12]. Immunological dysfunction along with bacterial translocation plays crucially in cirrhotic patients for catching infections [11] [12]. A recently described cirrhosis-associated immune dysfunction syndrome (CAIDS) is a multifactorial state of systemic immune dysfunction which decreases the ability to clear bacteria, cytokines, and endotoxins from circulation [13].

CAIDS has malfunctions of endothelial and reticular system, leukocytes dysfunction [14] with decreased bactericidal activity of ascitic fluid (decreased opsonization capacity, low levels of IgG, IgM, and IgA). Alteration in complement levels further contributes to CAIDS as evidenced by hypocomplementinemia where C3, C4, and CH50 are decreased both in serum and ascitic fluid [15]. Hepatic damage in chronic liver disease is responsible for hyperglobulinemia and cellular immune response inhibitions [16].

The most frequent infections reported among cirrhotics are spontaneous bacterial peritonitis (25\%), urinary tract infection (20\%), pneumonia (15\%), bacteremia (12\%), cellulitis or other infections [11] [12]. Amongst other identified pathogens in patients with cirrhosis are Mycobacterium tuberculosis, Clostridium difficile, Cryptococcus neoformans, Vibrio vulnificus, Yersinia enterocolitica, and Listeria monocytogenes. Bacterial infections in liver cirrhosis vary in presentation from being asymptomatic to having dearth of symptoms. Therefore any deterioration in general condition or of hepatic function should raise suspicion of infection in any patient with liver cirrhosis.

Pakistan being a proclaimed cirrhotic state already has a higher burden of morbidity and mortality with its various complications like hepatic encephalopathy, upper GI bleed and hepatorenal syndrome. Due to high morbidity and mortality of infections in cirrhosis, prevention, early diagnosis, and appropriate management of these infections are mandatory to improve survival. The objectives of the study were:

1) Determination of frequency and microbiological spectrum of infections in cirrhosis of liver.

2) Determination of risk factors for infections in cirrhosis of liver.

\section{Materials and Methods}

Local institutional ethics committee approval was sought before commencing the study. It is a hospital based, non-interventional, prospective cohort study performed on patients admitted with the diagnosis of cirrhosis of liver at Civil Hospital Karachi and Dow University of Health Sciences, Karachi, Pakistan from April 2007 to March 2012. All cirrhotic patients were arranged in two groups with infections and without infections. Infectious group includes the patients admitted with the diagnoses of hepatic cirrhosis, fever, bacteremia, sepsis, systemic inflammatory syndrome and septic shock. Each specific group of infection was defined by applying appropriate criteria.

\subsection{Cirrhosis of Liver}

Cirrhosis of liver was confirmed on clinical, biochemical, radiological (trans-abdominal ultrasound or comput- 
erized tomography showing a small shrunken liver with or without splenomegaly and intra-abdominal varices) and histopathological grounds, wherever required.

\subsection{Spontaneous Bacterial Peritonitis}

The diagnosis of spontaneous bacterial peritonitis was made by $>250$ neutrocytes in ascitic fluid with or without positive cultures for a specific organism and exclusion of other secondary causes of peritonitis [17].

\subsection{Culture Negative Neutrocytic Ascites}

This diagnosis was made over an elevated ascitic fluid absolute PMN count $\left(\geq 250\right.$ cells $\left./ \mathrm{mm}^{3}\right)$ with a negative ascitic fluid culture (in the absence of antibiotic therapy or pancreatitis) and without any evident source of infection in the abdomen which could be treated surgically [18].

\subsection{Monomicrobial Non Neutrocytic Bacterascites (MNB)}

Monomicrobial non-neutrocytic bacterascites (MNB) is diagnosed when single bacterium observed on Gram stain or cultured in non-neutrocytic ascites (i.e. PMN count $<250$ cells $/ \mathrm{mm}^{3}$ ) [19].

\subsection{Polymicrobial Bacterascites}

Traumatic paracentesis causes Polymicrobial bacterascites due to transient bacterial leak, from the gut into the fluid by the penetration of paracentesis needle [20]. Polymicrobial bacterascites is considered when multiple bacteria (polymicrobial) are observed on Gram stain or cultured in non-neutrocytic ascites (i.e. PMN count <250 cells $\left./ \mathrm{mm}^{3}\right)$ [20].

\subsection{Urinary Tract Infection}

The urinary tract infection was diagnosed on clinical grounds (dysuria, fever, flank pain), >15 WBC/hfp in urinalysis, with or without positive urine culture $\left(>10^{5} \mathrm{CFU} / \mathrm{ml}\right)[21]$.

\subsection{Respiratory Infections}

The diagnosis of respiratory tract infection was made on clinical symptoms and signs (cough, expectoration, pulmonary sounds, fever), positive radiologic signs (patchy alveolar opacities or non homogeneous opacity), with or without positive bacteriologic examination (sputum or blood culture) [2].

\subsection{Skin and Soft Tissue Infections}

The diagnosis of cutaneous and soft tissues infection was made by fever, local findings (pain, blush, tumefaction,), leukocytosis with neutrophilia, and positive cultures of wound secretions or blood [22].

\subsection{Central Nervous System Infections}

Bacterial meningitis was diagnosed in patients with clinical signs suggestive of meningitis and a positive CSF culture, or clinical findings and CSF polymorphonuclear pleocytosis (white blood cell count $>100 \mathrm{~mm}^{3}, 90 \%$ neutrophils). In the presence of negative Gram's stain and culture, meningitis of unknown origin was considered [23].

\subsection{Bacteremia}

Diagnosis of bacteremia was made by applying several criteria like positive blood culture for known organism or organism from saprophyte flora cultured from central line, signs like fever with rigors, hypotension to which the organism grown on blood culture has no relation with an infection to be found elsewhere [24].

\subsection{Sepsis and Septic Shock}

Sepsis and septic shock was diagnosed by applying the following clinical criteria: Fever $>38^{\circ} \mathrm{C}$ or hypothermia 
$\left(<36^{\circ} \mathrm{C}\right)$, tachycardia (pulse $\left.>90 / \mathrm{min}\right)$, tachypnea ( $\left.>20 / \mathrm{min}\right)$, hypoxemia $(<70 \mathrm{mmHg})$, metabolic acidosis, oliguria (diuresis $<30 \mathrm{ml} / \mathrm{min}$ ) [25].

\subsection{Malnutrition}

The final status of nutrition was established by applying royal free hospital global assessment (RFH-GA) scheme as shown in Figure 1. RFH-GA is a recently devised validated method for nutritional assessment in patient with liver cirrhosis. RFH-GA is a simple bedside assessment tool with both subjective and objective components required for nutritional assessment [26]. The subjective part of RFH-GA provides clinical information, dietary intake and physical status whereas objective component includes anthropometric measurements like mid arm muscle circumference (MAMC), body mass index (BMI) and Triceps skin fold thickness (TSF). This scheme integrates the subjective and objective portions of nutritional assessment in such a way that the cirrhotics can be quite vividly categorized into adequately nourished, moderately malnourished and severely malnourished.

\subsection{Statistical Analysis}

The data of the study was entered into Statistical Packages for the Social Sciences (SPSS) version 15.0 (SPSS Inc, Chicago, IL, USA) for statistical analysis. Mean and standard deviations were calculated for continuous variables while percentages and proportions were applied for discrete variables. The chi square test was applied to assess risk factors for infection by calculating odd ratio with $95 \%$ confidence and p-value of less than 0.05 was considered as statistically significant.

\section{Results}

Out of 1141 patients with cirrhosis of liver 490 (42.94\%) patients had infections. Apart from upper GI bleeding patients without infections 654 (57.16\%) were admitted due to other reasons like uncomplicated ascites (41\%), various stages of hepatic encephalopathy (29\%), electrolyte imbalance (21\%) and hepatoma (9\%). The mean age of patients with infections was 49 year \pm 13 SD as compared to 41 year \pm 10 SD years in non infectious group.

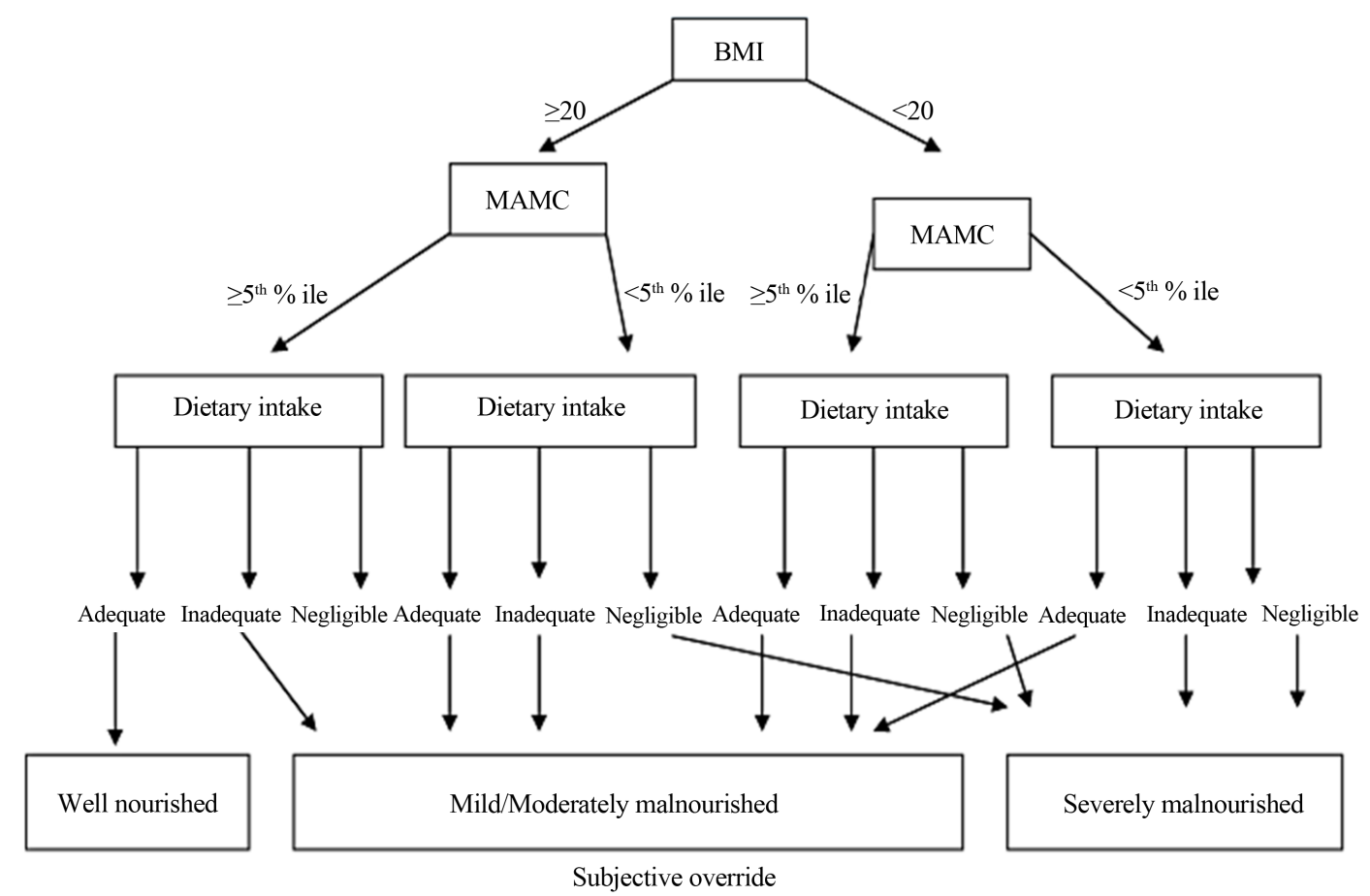

Figure 1. Royal free hospital gobal assessment scheme (RFH-GA Scheme) morgan et al., Hepatology, 2006. BMI: Body mass index; MAMC: Mid arm muscle circumference; \% ile: Percentile. 
The demographic profile of patients with and without infections is given in (Table 1). The most common cause of cirrhosis of liver was chronic viral hepatitis C, followed by hepatitis B, autoimmune hepatitis, PBC, Wilson's disease, haemochromatosis and alcohol. There were various kind of infections reported in cirrhotic patients. The frequencies of major group of infections found among cirrhotics are highlighted in (Table 2). The spectrum of microorganism, acquired versus nosocomial and their respective frequency has been shown in (Table 3).

Table 1. Demographic profile of patients.

\begin{tabular}{|c|c|c|c|}
\hline & Total patients & With infections & Without infections \\
\hline & $\mathrm{n}=1141$ & $n=490$ & $n=651$ \\
\hline Age & & 49 years $\pm 13 \mathrm{SD}$ & 41 years \pm 10 SD \\
\hline \multicolumn{4}{|l|}{ Gender } \\
\hline Male & 696 (60.99\%) & 299 (42.95\%) & 397 (57.04\%) \\
\hline Female & 455 (39.87\%) & 191 (41.97\%) & 254 (55.82\%) \\
\hline \multicolumn{4}{|l|}{ Severity of liver cirrhosis } \\
\hline Compensated & 388 (34.00\%) & 39 (10.05\%) & 349 (89.94\%) \\
\hline Decompensated & 753 (65.99\%) & 451 (59.89\% & $302(40.01 \%)$ \\
\hline CTP-A & $52(6.90 \%)$ & 03 (5.7\%) & 49 (94.23\%) \\
\hline CTP-B & $240(31.87 \%)$ & 89 (37.08\%) & 151 (62.91\%) \\
\hline CTP-C & $461(61.22 \%)$ & 359 (77.87\%) & $102(22.12 \%)$ \\
\hline Ascites & $501(43.90 \%)$ & 220 (43.91\%) & $281(56.08 \%)$ \\
\hline \multicolumn{4}{|l|}{ Aetiology } \\
\hline Chronic hepatitis C & 547 (47.94\%) & 235 (42.96\%) & 312 (57.03\%) \\
\hline Chronic hepatitis B & 414 (36.28\%) & 177 (42.75\%) & 237 (57.24\%) \\
\hline Autoimmune hepatitis & $51(4.46 \%)$ & 177 (42.75\%) & $29(56.86 \%)$ \\
\hline PBC & $46(4.03 \%)$ & $20(43.45 \%)$ & $26(56.52 \%)$ \\
\hline Wilsons disease & 39 (3.41\%) & 17 (43.58\%) & $22(56.41 \%)$ \\
\hline Alcohol & 25 (2.19\%) & $11(44 \%)$ & $14(56 \%)$ \\
\hline Haemochromatosis & 19 (1.66\%) & $08(42.10 \%)$ & $11(57.89 \%)$ \\
\hline
\end{tabular}

Table 2. Occurrence rates of assorted infections in cirrhosis of liver.

\begin{tabular}{ccc}
\hline Type of infection & $\begin{array}{c}\text { Total patients of cirrhosis } \\
\text { with infection }=490 \mathrm{~N}=\text { number }\end{array}$ & $\begin{array}{c}\text { Frequency of } \\
\text { infection \% }\end{array}$ \\
\hline Ascetic fluid infections (AFI) & $\mathrm{N}=220$ & $44.89 \%$ \\
Urinary tract infections (UTI) & $\mathrm{N}=103$ & $21.02 \%$ \\
Respiratory tract infections (RTI) & $\mathrm{N}=88$ & $17.98 \%$ \\
Tuberculosis (TB) & $\mathrm{N}=44$ & $8.97 \%$ \\
Skin and soft tissue infections & $\mathrm{N}=21$ & $4.26 \%$ \\
Liver abscess & $\mathrm{N}=5$ & $1.02 \%$ \\
Central nervous system infections (CNS infections) & $\mathrm{N}=9$ & $1.83 \%$ \\
\hline
\end{tabular}


Table 3. Type, frequency and microbiological spectrum of infections in cirrhosis of liver.

\begin{tabular}{|c|c|c|c|}
\hline Type of infection & $\begin{array}{l}\text { Frequency } \\
\text { of infection }\end{array}$ & $\begin{array}{l}\text { Community } \\
\text { acquired/nosocomial }\end{array}$ & Spectrum of organism cultured \\
\hline Ascites fluid infection & $\mathrm{N}=220(44.89 \%)$ & & \\
\hline SBP & $\mathrm{N}=85(38.63 \%)$ & & $\begin{array}{c}\text { E. coli } 36 \text { (42.35\%), Streptococcus } \\
\text { pneumonia } 13(15.29 \%), \text { Pseudomonas species } \\
11(12.94 \%) \text { Staphylococcus species } 9(10.58 \%), \\
\text { Enterococcus species } 6 \text { (7.05\%), Klebsiella } 5(5.88 \%), \\
\text { Bacillus species } 3 \text { (3.52\%), Group D Streptococcus } \\
1(1.17 \%), \text { Acitenobacter } 1(1.17 \%)\end{array}$ \\
\hline CNNA & $\mathrm{N}=127(57.72 \%)$ & & No growth \\
\hline MNB & $\mathrm{N}=7(3.18 \%)$ & & $\begin{array}{c}\text { E. coli } 3 \text { (42.85\%), Enterococcus } 2 \text { (28.57\%), } \\
\text { Pseudomonas } 02 \text { (28.57\%) }\end{array}$ \\
\hline PMB & $\mathrm{N}=1(0.45 \%)$ & & Enterococcus, Pseudomonas species, Bacillus species \\
\hline \multirow[t]{2}{*}{ UTI } & $\mathrm{N}=103(21.02 \%)$ & $\begin{array}{l}\text { Community acquired }= \\
97(94.17 \%)\end{array}$ & $\begin{array}{c}\text { E. coli } 71 \text { (73.19\%), Klebsiella } 12(12.37 \%), \\
\text { Pseudomonas species } 5(5.15 \%), \\
\text { Enterococcus } 3 \text { (3.09\%), proteus } 4(4.12 \%), \\
\text { Staphylococcus species } 2 \text { (2.06\%). }\end{array}$ \\
\hline & & Nosocomial = 7 (6.79\%) & $\begin{array}{l}\text { E. coli } 3(42.87 \%) \text {, Pseudomonas species } \\
2 \text { (28.57\%), Klebsiella } 2(28.57 \%)\end{array}$ \\
\hline \multirow[t]{2}{*}{ RTI } & $\mathrm{N}=88(17.98 \%)$ & $\begin{array}{l}\text { Community acquired = } \\
79(89.77 \%)\end{array}$ & $\begin{array}{c}\text { Streptococcus pneumonia } 56 \text { (70.88\%), } \\
\text { Haemophilus influenzae } 8 \text { (10.12\%), Klebsiella } 6 \text { (7.54\%), } \\
\text { mycoplasma } 4 \text { (5.06\%) Pseudomonas } 3 \text { (3.79\%), } \\
\text { Legionella } 2 \text { (2.53\%) }\end{array}$ \\
\hline & & Nosocomial = $9(11.36 \%)$ & Staphylococcus 5 (55.55\%), Pseudomonas 4 (44.44\%) \\
\hline TB & $\mathrm{N}=44(8.97 \%)$ & $\begin{array}{l}\text { Community acquired }=44 \\
\quad \text { Nosocomial }=\text { nil }\end{array}$ & \\
\hline Peritoneal & $\mathrm{N}=34(77.27 \%)$ & & $\begin{array}{c}4(11.76 \%) \text { were AFB culture positive, } \\
24 \text { (70.55\%) were diagnosed on ascetic fluid analysis, } \\
4(11.76 \%) \text { with positive PCR of mycobacterium, } \\
\text { and } 2 \text { (5.88\%) on laparoscopic biopsy. }\end{array}$ \\
\hline Intestinal & $\mathrm{N}=6(13.36 \%)$ & & $\begin{array}{l}4 \text { (66.66\%) were diagnosed with imaging (findings } \\
\text { on Ultra sound + Barium meal, barium enema, and CT } \\
\text { abdomen). } 2 \text { (33.33\%) were diagnosed on histopathology. }\end{array}$ \\
\hline Pulmonary & $\mathrm{N}=4(9.09 \%)$ & & All cases were AFB smear positive \\
\hline Skin and soft tissue & $\mathrm{N}=21(4.26 \%)$ & $\begin{array}{l}\text { All Community acquired } \\
\text { Nosocomial = nil }\end{array}$ & \\
\hline Cellulites & 12 & & $\begin{array}{c}\text { E. coli } 7 \text { (58.33\%), streptococcus } 3(25 \%) \\
\text { Staphylococcus } 1 \text { (8.33\%), pseudomonas } 1(8.33 \%)\end{array}$ \\
\hline Heamorrhagic bullae & $6(28.57 \%)$ & & $\begin{array}{c}\text { E. coli } 3(50 \%) \text {, pseudomonas } 1(16.66 \%) \\
\text { Streptococcus } 1(16.66 \%) \text {, Staphylococcus } 1(16.66 \%)\end{array}$ \\
\hline Abscess & $3(14.28 \%)$ & & E. coli 2 (66.6\%), Streptococcus 1 (33.33\%) \\
\hline Liver abscess & $\mathrm{N}=5(1.02 \%)$ & All community acquired & \\
\hline Amoebic & $\mathrm{N}=1(20 \%)$ & & Entamoeba histolytica \\
\hline Pyogenic & $\mathrm{N}=4(80 \%)$ & & $\begin{array}{l}\text { E. coli } 2 \text { (50\%), Klebsiella } 1 \text { (25\%), } 1 \text { (25\%) } \\
\text { mixed growth of Pseudomonas and Bacteroid }\end{array}$ \\
\hline CNS Infection & $\mathrm{N}=9(1.83 \%)$ & & \\
\hline Meningitis & 7 (77.77\%) & & $\begin{array}{c}\text { Klebsiella } 3 \text { (42.85\%), Streptococcus } 1(14.28 \%) \\
\text { listeria monocytogens } 1 \text { (14.28\%). } 2 \text { (28.57\%) } \\
\text { were culture negative. }\end{array}$ \\
\hline encephalitis & 2 (22.22\%) & & \\
\hline
\end{tabular}




\subsection{Ascitic Fluid Infections (AFI)}

Ascitic fluid infections (AFI) were the commonest $44.89 \%$ in cirrhotics. Among ascitic fluid infections 85 (38.63\%) patients had SBP. The most notorious organism found in SBP were E. coli 36 (42.35\%), Streptococcus pneumonia 13 (15.29\%), Pseudomonas species 11 (12.94\%) Staphylococcus species 9 (10.58\%), Enterococcus species 6 (7.05\%), Klebsiella 5 (5.88\%), Bacillus species 3 (3.52\%), Group D Streptococcus 1 (1.17\%) and Acinetobacter 1 (1.17\%). 57.72\% patients had culture negative neutrocytic ascites (CNNA), while 7 (3.18\%) had monomicrobial bacterascites (MNB) and only one patient $(0.45 \%)$ had polymicrobial bacterascites (PMB).

\subsection{Urinary Tract Infections (UTI)}

Among 490 cirrhotic patients with infection 103 (21.02\%) patients had UTI. 94.17\% infections were community acquired while $6.79 \%$ were nosocomial. The spectrum of microorganism cultured in community acquired UTI were E. coli 71 (73.19\%), Klebsiella 12 (12.37\%), Pseudomonas species 5 (5.15\%), Enterococcus 3 (3.09\%), Proteus 4 (4.12\%) and Staphylococcus species 2 (2.06\%). The nosocomial UTI had a different microbial spectrum with E. coli 3 (42.87\%), Pseudomonas species 2 (28.57\%), Klebsiella 2 (28.57\%).

\subsection{Respiratory Tract Infections (RTI)}

Out of total 490 patients with infections among cirrhotics, respiratory infections were present in 88 patients (17.98\%). Majority of infections (89.77\%) were community acquired while the rest were nosocomial (11.36\%). The spectrum of microorganism cultured in community acquired background were Streptococcus pneumonia (70.88\%), Haemophilus influenzae (10.12\%), Klebsiella (7.54\%), Mycoplasma (5.06\%), Pseudomonas (3.79\%) and Legionella (2.53\%). Staphylococcus 5 (55.55\%), Pseudomonas 4 (44.44\%) were identified in nosocomial group.

\subsection{Tuberculosis}

44 (8.97\%) patients with cirrhosis of liver had various forms of TB. Main form of TB was peritoneal (77.27\%) followed by (13.36\%) intestinal and $(9.09 \%)$ had pulmonary TB. The diagnostic frequency by various methods for TB has been summarized (Table 3 ).

\subsection{Skin and Soft Tissue Infections}

Twenty one (4.26\%) patients had soft tissue and skin infections. The commonest infection was cellulitis with microbiological spectrum of E. coli (58.33\%), streptococcus (25\%), Staphylococcus (8.33\%), pseudomonas (8.33\%). Six (28.57\%) patients had haemorrhagic bullae where cultured micro-organisms were E. coli (50\%), pseudomonas (16.66\%), Streptococcus (16.66\%) and Staphylococcus (16.66\%). The abscesses were present in (14.28\%) where identified organisms were E. coli (66.6\%) and Streptococcus (33.33\%).

\subsection{Liver Abscess}

Five patients (1.02\%) had liver abscess. One patient (20\%) had amoebic liver abscess while 4 (80\%) patients had pyogenic abscess. Out of Pyogenic abscesses cultured organisms were E. coli 2 (50\%), Klebsiella 1 (25\%), 1 (25\%) had mixed growth of Pseudomonas and Bacteroid.

\subsection{Central Nervous System Infections}

Nine (1.83\%) patients had central nervous system infections. Most common infection was meningitis (77.77\%) and encephalitis (22.22\%). The cultured organisms in meningitis were Klebsiella 3 (42.85\%), Streptococcus 1 (14.28\%) Listeria monocytogens 1 (14.28\%). Two (28.57\%) were culture negative.

\subsection{Risk Factors for Infection in Cirrhosis}

\subsubsection{Upper GI Bleeding}

Out of 1141 cirrhotics, 684 (59.94\%) patients presented with upper GI bleed. Among patients with upper GI bleeding 403/684 (58.91\%) had infection with the calculated odd ratio $=4.57$ (95\% CI $3.48-6.01)$ and p value 
of 0.0001 as shown in (Table 4).

\subsubsection{Use of PPI}

Among 1141 cirrhotics 446 (39.05\%) patients were on proton pump inhibitors where 228 out of 446 on PPI $(51.12 \%)$ had infections with calculated odd ratio $=2.57(95 \%$ CI $1.99-3.319)$ and $p$ value of 0.000 as given in (Table 4).

\subsubsection{Degree of Malnutrition}

Out of 1141 cirrhotics, 810 (70.99\%) patients were malnourished. Two thirty five (29.01\%) patients were mild to moderately malnourished according to RFH-GA scheme while five seventy five (78.95\%) were severely malnourished. Among mild to moderate category 126/235 (53.61\%) patients had infections with calculated odd ratio $=7.38(\mathrm{CI} 95 \%, 3.57-14.78, \mathrm{p}$ value $=0.000)$. The frequency of infection was even higher 360/575 $(62.60 \%)$ in severely malnourished patients with calculated odd ratio $=10.34(95 \%$ CI $6.81-15.75, \mathrm{p}=0.0001)$ shown in (Table 4).

\subsubsection{Severity of Liver Disease}

Out of 1141 cirrhotics, 388 (34\%) had compensated liver disease while 753 (65.99\%) patients were decompensated. Among decompensated disease frequency of infection was 59.89\% while in compensated disease it was just 10.05\%. The overall degree of decompensation categorized as CTP-A, CTP-B and CTP-C was assessed as a risk factor for infection. Out of 753 patients with decompensation (CTP-A, CTP-B and CTP-C) 59.89\% had infection with calculated odd ratio $=12.99(\mathrm{CI} 95 \%, 8.95-18.90$, $\mathrm{p}$ value $=0.000)$ as shown in (Table 4).

\section{Discussion}

Increased frequency of various infections among cirrhotics along with complications like HE, upper GI bleed, ascites and renal failure pose even bigger challenge in reducing morbidity and mortality. In this study mean age of patients with infection was 49 year \pm 13 SD years which is different from earlier studies where mean age was 54.4 and 69.5 years respectively [27] [28]. The frequency of infection among male (42.95\%) and female cirrhotics (41.97\%) were different in this study from previous study [29]. An earlier study showed slightly higher frequency among males $57 \%$ as compared to females $43 \%$ [27].

The commonest cause of cirrhosis in this study was chronic hepatitis $C$ and B. Where approximately $60 \%-70 \%$ of the cirrhotics are anti HCV positive, the frequency matches the prevalence of viral related hepatitis in Pakistan [30]. Positioned in the intermediate HBV prevalence area, Pakistan has a carrier rate of $3 \%-4 \%$ [31] which typically emphasizes that here HBV is an important cause of cirrhosis of liver [30]. Alcohol found as the commonest cause of liver cirrhosis in western countries contrasted to our study due to religious prohibition among Muslims.

\section{Table 4. Risk factors for infections in cirrhosis of liver.}

\begin{tabular}{|c|c|c|c|c|c|c|}
\hline $\begin{array}{c}\text { Risk factor for } \\
\text { infection in cirrhosis }\end{array}$ & Total patients & With infections & $\begin{array}{l}\text { With out } \\
\text { infections }\end{array}$ & Odd ratio & $\begin{array}{c}\text { Confidence } \\
\text { interval 95\% }\end{array}$ & p value \\
\hline $\begin{array}{c}\text { Degree of decompensation } \\
\text { CTP-A, CTP-B, CTP-C }\end{array}$ & $\mathrm{N}=753(65.99 \%)$ & $\mathrm{N}=451(58.98 \%)$ & $\mathrm{N}=302(40.10 \%)$ & 12.99 & $8.95-18.90$ & 0.0001 \\
\hline Upper GI bleeding & $\mathrm{N}=684(59.94 \%)$ & $\mathrm{N}=403(58.91)$ & $\mathrm{N}=281(41.08 \%)$ & 4.57 & $3.48-6.01$ & 0.0001 \\
\hline Use of PPI & $\mathrm{N}=446(39.05 \%)$ & $\mathrm{N}=228(51.12 \%)$ & $N=218(48.87 \%)$ & 2.57 & $1.99-3.319$ & 0.0001 \\
\hline \multicolumn{7}{|l|}{$\begin{array}{l}\text { Degree of malnutrition } \\
\text { according to RFH-GA } \\
\text { Scheme }\end{array}$} \\
\hline Over all & $\mathrm{N}=810(70.99 \%)$ & $\mathrm{N}=486(60 \%)$ & $\mathrm{N}=324(40 \%)$ & 4.273 & $3.18-5.73$ & 0.0001 \\
\hline Mild to moderate & $\mathrm{N}=235$ (29.01\%) & $\mathrm{N}=126(53.61 \%)$ & $\mathrm{N}=109(86.50 \%)$ & 7.38 & $3.57-14.78$ & 0.0001 \\
\hline Severe & $\mathrm{N}=575(70.98 \%)$ & $\mathrm{N}=360(62.60 \%)$ & $\mathrm{N}=215$ (37.39\%) & 10.34 & $6.81-15.75$ & 0.0001 \\
\hline
\end{tabular}


Most of the patients in this study (65.99\%) had overall decompensated cirrhosis with further scoring of (Child-Pugh C 61.22\%, 31.87\% Child-Pugh B and 6.90\% child Pugh A) which is similar to earlier studies [32] [33]. An earlier study [34] has contrasted to our study and showed less advanced chronic liver disease (ChildPugh C 15\% and 35\% Child-Pugh B). More severe disease in this study as compared to western studies is probably due to futile health care system, lack of education, poverty and false believes about disease.

The frequency of infection among cirrhotics is very high (42.94\%) in this study. Earlier conducted studies on the admitted patients with cirrhosis [2] had shown lower frequency of bacterial infections that is $32 \%$ to $34 \%$. The high rate of infection in this study is probably due to more severe disease, lack of health care facilities, non affordance and loss to follow up. The infections were found more in decompensated cirrhosis (59.89\%) than compensated cirrhosis (10.05\%). An earlier retrospective study showed 98\% infection among decompensated cirrhosis and only $2 \%$ infection in compensated disease [27].

Ascitic fluid infections were the most commonly (44.89\%) encountered infections in this study. All kind of ascitic fluid infections like SBP, CNNA, MNB and PMB were observed in this study. Out of Ascitic fluid infections SBP was (38.63\%) with E. coli being the most common (42.35\%) cultured microorganism followed by streptococcus pneumonia, Pseudomonas species, Staphylococcus species, Enterococcus species, Klebsiella, Bacillus, Group D Streptococcus and Acinetobacter. Fernandez J, et al. [2] had shown 25\% SBP among patients with cirrhosis of liver. Earlier published local studies on AFI showed frequency of SBP to be (23.5\%) and (38.23\%) respectively with similar microbiological spectrum [35] [36]. The low frequency of SBP in above studies is probably due to smaller sample size. 69.93\% patients among AFI had CNNA in this study. Above mentioned studies had (76.4\%) and (57.84\%) CNNA [35] [36].

Urinary tract infections were present in (21.02\%) patients, majority of infections were community acquired while few of the nosocomial were also recorded. Earlier study reported that urinary tract infections account for $12 \%$ to $29 \%$ of infectious complications found in decompensated cirrhotic patients [37]. Two other studies [11] [12] also showed similar frequency of UTI in cirrhotic patients. Most notorious organisms responsible for UTI in this study were E. coli, Klebsiella and Pseudomonas in community acquired group. Cruz et al. [38] also reported 5\% UTI in cirrhotic patient with E. coli, Klebsiella. Fasolato et al. [28] had shown urinary tract infections (46.2\%) without ascites and (42.3\%) with ascites.

Among (17.98\%) patients with respiratory infection, both community and nosocomial pneumonia was present in this study. Major organism isolated from community acquired pneumonia was streptococcus pneumonia, $\mathrm{H}$. influenza and Klebsiella. The results are similar to previous studies [27] [39]. Fasolato et al. [28] have also reported slightly higher frequency (24.0\%) of Pneumonia in cirrhotics. Most of the nosocomial respiratory infections occurred in patients with severe disease, having hepatic encephalopathy who were shifted to intensive care unit. Staphylococcus and pseudomonas were main organisms in nosocomial infections in this study.

Various forms of TB were found in this study. Most common type of TB was peritoneal (77.27\%) and intestinal (13.36\%) while (9.09\%) patients had pulmonary TB. Shakil et al. [40] reported 90\% of cases of mixed tuberculous peritonitis (TBP) in alcoholic related cirrhosis. However, peritoneal TB is unremarkable in non-alcoholic cirrhotics [41]. Studies from the western world [40] imply 62\% of TBP with cirrhosis; conversely data from developing nations propose rather lower concurrent rates of $13 \%$ [42].

In a large retrospective study from India [43], the estimated prevalence of TB in cirrhotics was 73.8/1000 where TB was most common in alcohol related cirrhosis (60\%) followed by post viral infection $28 \%$ (hepatitis B and C). In this study TB was mainly related to viral cirrhosis because rate of alcoholic cirrhosis is very low. In this study extra pulmonary sites were peritoneum and intestine in contrast to the above Indian study where extra pulmonary TB was observed to be more common in the cirrhotic patients with involvement of pleura (28\%); peritoneum (18\%); cervical lymph nodes (6\%); liver (4\%); intestines (2\%); and vertebrae (2\%). Yoo et al. have also reported a higher incidence of extra pulmonary involvement in cirrhotic patients [44]. A Danish nationwide population based study showed incidence rate of TB among cirrhotics to be 168.6 per 100000 person/year, [45] further suggesting that cirrhosis of liver is an independent risk factor for tuberculosis.

Soft tissue infections constitute approximately $11 \%$ of all infections among cirrhotics. Increased bacterial translocation and persistent edema predispose patients with cirrhosis to soft tissue infections [46]. Soft tissue infections are caused by both gram positive (Group A Streptococci, S. aureus) and gram negative organisms like Klebsiella, $V$. vulnificus and Aeromonas species. Cellulitis is the most commonly observed skin infection in patients with cirrhosis having a reported recurrence rate of 20\% [47]. Soft tissue infections observed in this study were in accordance to previous studies as cellulitis was the commonest followed by abscess, haemorrhagic bullae. 
The E. coli was the most common organism cultured from skin aspirates or blood in our study. An earlier study frequently reported skin infection with E. coli [47].

In this study gram positive organism were also cultured in soft tissue infections like cellulitis but interestingly most of these patients had a prior trauma that led to cellulitis. This is in accordance with earlier study by Mohan P et al. [48] where gram positive pathogens were identified in cellulitis only in those cirrhotics who had history of trauma. Why E. coli was the most common organism in skin infections amongst cirrhotics? It is not completely understood. It may be related to reduced clearance of enteric organisms by Kupffer cells and defective bactericidal activity of IgM against E. coli.

Liver abscess is rare in patients with cirrhosis of the liver. This study shows (1.02\%) liver abscess with more frequency of pyogenic versus amoebic abscess. Gram-negative aerobes were the predominant pathogens (E. coli, 50\%), (Klebsiella, 25\%) while 25\% showed mixed growth of Pseudomonas and Bacteroid. Our study is congruent with an earlier retrospective study [49] where incidence of liver abscess in the cirrhotic patients was low, at 0.09\%. The spectrum of pathogen was slightly different from this study (Klebsiella pneumoniae, 66.7\%; Escherichia coli, $23.8 \%$ ), while $38 \%$ of cases showed polymicrobial pathogens.

Among overall CNS infections (1.83\%) within cirrhotics, bacterial meningitis (77.77\%) was the most common while viral encephalitis was also noted in this study. Bacterial meningitis with special complications and poor outcome has been described in few earlier published series [50]. In our study the most common organism was Klebsiella while Cabellos et al. [23] showed a lower frequency (4.8\%) of bacterial meningitis in cirrhotics where Nesseria meningitides and S. pneumonia were shown to be the main culprits. A recent study on community acquired bacterial meningitis in cirrhotics showed $40 \%$ frequency of bacterial meningitis. Klebsiella pneumoniae was the most frequent causative pathogen in above study which is comparable to our study [51].

Upper GI bleeding is a major risk factor for infection in this study where calculated odd ratio $=2.57$ (95\% CI 1.99 - 3.319) and $p$ value of 0.0001. Our result is similar to the earlier studies [5]-[9] where upper GI bleed was independently associated with bacterial infections. Another risk factor evaluated for bacterial infection in this study was the use of PPI. Among 1141 cirrhotics 446 (39.05\%) patients were on proton pump inhibitors where 228 out of 446 on PPI (51.12\%) had infections with calculated odd ratio $=2.57$ (95\% CI 1.99 - 3.319) and p value of 0.000 . Bajaj JS et al. [52] in their study showed that the use of PPI was independently associated with SBP (odds ratio 4.31, confidence interval 1.34 - 11.7), and protein within ascitic fluid was found to be protective (OR 0.1, CI $0.03-0.25$ ). The above study also revealed that $47 \%$ of cirrhotic patients receiving PPI had no documented indication for PPI treatment. A recent study on risk factors for bacterial infections among cirrhotics has shown that use of PPI (OR = 3.443, 95\% CI $1.164-10.188$; $p=0.025)$ was a risk factor for SBP [53].

The severity of liver disease is a well known risk factor for bacterial infections in cirrhotics. Out of 753 patients with decompensation (CTP-A, CTP-B and CTP-C) $65.99 \%$ in this study had infection with calculated odd ratio = $12.99(\mathrm{p}$ value $=0.000 \mathrm{CI} 95 \%, 8.95-18.90)$.

Earlier studies [4] [27] are also comparable with our study where severe liver disease (hepatic decompensation) was associated with high frequency of bacterial infections. Protein calorie malnutrition has been reported in 60 to 100 percent of patients with decompensated cirrhosis and up to 20 percent with compensated cirrhosis [54] [55]. Malnourishment among patients with liver cirrhosis accompanies a higher rate of infections and other complications [56]. We evaluated various degree of malnutrition as risk factor for infections among cirrhotics where within mild to moderate category (53.61\%) patients had infections with calculated odd ratio $=7.38$ (CI 95\%, 3.57 - 14.78, p value $=0.000$ ). The rate of infection was even higher $(62.60 \%)$ in severely malnourished patients with calculated odd ratio $=10.34(95 \%$ CI $6.81-15.75, \mathrm{p}=0.0001)$. Merli et al. [57] in their recent prospective study of cirrhotic cohort identified protein malnutrition ( $\mathrm{p}=0.04$; 95\% CI, $1.5-10$ ) as an independent predictor of infection.

\section{Conclusion}

All type of infections occurred with increased frequency in cirrhosis of liver. Upper GI bleed, severity of cirrhosis, high dose of proton pump inhibitors and severe malnutrition all are established risk factors for infections among cirrhotics.

\section{References}

[1] Tandon, P. and Garcia-Tsao, G. (2008) Bacterial Infections, Sepsis, and Multiorgan Failure in Cirrhosis. Seminars in 
Liver Disease, 28, 26-42. http://dx.doi.org/10.1055/s-2008-1040319

[2] Fernandez, J., Navasa, M., Gómez, J., et al. (2002) Bacterial Infections in Cirrhosis: Epidemiological Changes with Invasive Procedures and Norfloxacin Prophylaxis. Hepatology, 35, 140-148. http://dx.doi.org/10.1053/jhep.2002.30082

[3] Arvaniti, V., D’Amico, G., Fede, G., et al. (2010) Infections in Patients with Cirrhosis Increase Mortality 4-Fold and Should Be Used in Determining Prognosis. Gastroenterology, 139, 1246-1256. http://dx.doi.org/10.1053/j.gastro.2010.06.019

[4] Borzio, M., Salerno, F., Piantoni, L., et al., (2001) Bacterial Infection in Patients with Advanced Cirrhosis: A Multicentre Prospective Study. Digestive and Liver Disease, 33, 41-48. http://dx.doi.org/10.1016/S1590-8658(01)80134-1

[5] Bernard, B., Grange, J.D., Khac, E.N., Amiot, X., et al. (1999) Antibiotic Prophylaxis for the Prevention of Bacterial Infections in Cirrhotic Patients with Gastrointestinal Bleeding: A Meta-Analysis. Hepatology, 29, 1655-1661. http://dx.doi.org/10.1002/hep.510290608

[6] Goulis, J., Armonis, A., Patch, D., Sabin, C., Greenslade, L. and Burroughs, A.K. (1998) Bacterial Infection Is Independently Associated with Failure to Control Bleeding in Cirrhotic Patients with Gastrointestinal Hemorrhage. Hepatology, 27, 1207-1212. http://dx.doi.org/10.1002/hep.510270504

[7] Vivas, S., Rodriguez, M., Palacio, M.A., Linares, A., Alonso, J.L. and Rodrigo, L. (2001) Presence of Bacterial Infection in Bleeding Cirrhotic Patients Is Independently Associated with Early Mortality and Failure to Control Bleeding. Digestive Diseases and Sciences, 46, 2752-2757. http://dx.doi.org/10.1023/A:1012739815892

[8] Bernard, B., Cadranel, J.F., Valla, D., Escolano, S., Jarlier, V. and Opolon, P. (1995) Prognostic Significance of Bacterial Infection in Bleeding Cirrhotic Patients: A Prospective Study. Gastroenterology, 108, 1828-1834. http://dx.doi.org/10.1016/0016-5085(95)90146-9

[9] Hou, M.C., Lin, H.C., Liu, T.T., et al. (2004) Antibiotic Prophylaxis after Endoscopic Therapy Prevents Rebleeding in Acute Variceal Hemorrhage: A Randomized Trial. Hepatology, 39, 746-753. http://dx.doi.org/10.1002/hep.20126

[10] Wong, F., Bernardi, M., Balk, R., et al. (2005) Sepsis in Cirrhosis: Report on the 7th Meeting of the International Ascites Club. Gut, 54, 718-725. http://dx.doi.org/10.1136/gut.2004.038679

[11] Navasa, M. and Rodés, J. (2004) Bacterial Infections in Cirrhosis. Liver International, 24, 277-280. http://dx.doi.org/10.1111/j.1478-3231.2004.0934.x

[12] Vilstrup, H. (2003) Cirrhosis and Bacterial Infections. Romanian Journal of Gastroenterology, 12, $297-302$.

[13] Talwani, R., Gilliam, B.L. and Howell, C. (2011) Infectious Diseases and the Liver. Clinics in Liver Disease, 15, 111130. http://dx.doi.org/10.1016/j.cld.2010.09.002

[14] Wasmuth, H.E., Kunz, D., Yagmur, E., et al. (2005) Patients with Acute on Chronic Liver Failure Display "SepsisLike” Immune Paralysis. Journal of Hepatology, 42, 195-201. http://dx.doi.org/10.1016/j.jhep.2004.10.019

[15] Ono, Y., Watanabe, T., Matsumoto, K., et al. (2004) Opsonophagocytic Dysfunction in Patients with Liver Cirrhosis and Low Responses to Tumor Necrosis Factor-Alpha and Lipopolysaccharide in Patients' Blood. Journal of Infection and Chemotherapy, 10, 200-207. http://dx.doi.org/10.1007/s10156-004-0321-7

[16] Wiest, R. and Garcia-Tsao, G. (2005) Bacterial Translocation (BT) in Cirrhosis. Hepatology, 41, 422-433. http://dx.doi.org/10.1002/hep.20632

[17] Caruntu, F.A. and Benea, L. (2006) Spontaneous Bacterial Peritonitis: Pathogenesis, Diagnosis, Treatment. Journal of Gastrointestinal and Liver Diseases, 15, 51-56.

[18] Runyon, B.A. and Hoefs, J.C. (1984) Culture-Negative Neutrocytic Ascites: A Variant of Spontaneous Bacterial Peritonitis. Hepatology, 4, 1209. http://dx.doi.org/10.1002/hep.1840040619

[19] Runyon, B.A. (1990) Monomicrobial Non Neutrocytic Bacterascites: A Variant of Spontaneous Bacterial Peritonitis. Hepatology, 12, 710. http://dx.doi.org/10.1002/hep.1840120415

[20] Runyon, B.A., Hoefs, J.C. and Canawati, H.N. (1986) Polymicrobial Bacterascites. A Unique Entity in the Spectrum of Infected Ascitic Fluid. Archives of Internal Medicine, 146, 2173. http://dx.doi.org/10.1001/archinte.1986.00360230099015

[21] Cadranel, J.F., Denis, J., Pauwels, A., et al. (1999) Prevalence and Risk Factors of Bacteriuria in Cirrhotic Patients: A Prospective Case Control Multicenter Study in 244 Patients. Journal of Hepatology, 31, 464-468. http://dx.doi.org/10.1016/S0168-8278(99)80038-5

[22] Mohan, P., Ramu, B., Bhaskar, E., et al. (2011) Prevalence and Risk Factors for Bacterial Skin Infection and Mortality in Cirrhosis. Annals of Hepatology, 10, 15-20.

[23] Cabellos, C., Viladrich, P.F., Ariza, J., Maiques, J.M., Verdaguer, R. and Gudiol, F. (2008) Community-Acquired Bacterial Meningitis in Cirrhotic Patients. Clinical Microbiology and Infection, 14, 35-40. http://dx.doi.org/10.1111/j.1469-0691.2007.01839.x 
[24] Ruiz-del-Arbor, L., Urman, J., Fermandez, J., et al. (2003) Cardiovascular, Renal and Hepatic Hemodynamic Derangement in Cirrhotic Patients with Spontaneous Bacterial Peritonitis. Hepatology, 38, 1210-1218. http://dx.doi.org/10.1053/jhep.2003.50447

[25] Lehner, S., Stemmler, H.J., Mück, A., et al. (2010) Prognostic Parameters and Risk Stratification in Intensive Care Patients with Severe Liver Diseases. Journal of Gastrointestinal and Liver Diseases, 19, 399-404.

[26] Morgan, M.Y., Madden, A.M., Soulsby, C.T. and Morris, R.W. (2006) Derivation and Validation of a New Global Method for Assessing Nutritional Status in Patients with Cirrhosis. Hepatology, 44, 823-835. http://dx.doi.org/10.1002/hep.21358

[27] Preda, C.M., Ghita, R., Ghita, C., et al. (2011) A Retrospective Study of Bacterial Infections in Cirrhosis. Journal of Clinical Medicine, 6, 185.

[28] Fasolato, S., Angeli, P., Dallagnese, L., Maresio, G., et al. (2007) Renal Failure and Bacterial Infections in Patients with Cirrhosis: Epidemiology and Clinical Features. Hepatology, 45, 223-229. http://dx.doi.org/10.1002/hep.21443

[29] Ferreira, T., Sevá-Pereira, T., Almeida, J., Fioravante, M., Yamanaka, A., et al. (2012) Impact of Infection in Hospitalized Cirrhotic Patients in a University Hospital. Open Journal of Gastroenterology, 2, 124-130. http://dx.doi.org/10.4236/ojgas.2012.23026

[30] Khan, A.A., Rehman, K.U., Haider, Z. and Shafqat, F. (2002) Sero-Markers of Hepatitis B and C in Patients with Cirrhosis. Journal of the College of Physicians and Surgeons Pakistan, 12, 105-107.

[31] Andre, F. (2000) Hepatitis B Epidemiology in Asia: The Middle East and Africa. Vaccine, 18, S20-S22. http://dx.doi.org/10.1016/S0264-410X(99)00456-9

[32] Butt, S., Ahmed, P., Liaqat, P. and Ahmed, H. (2009) A Study of Malnutrition among Liver Disease Patients. Pak Nut, 8, 1465-1471. http://dx.doi.org/10.3923/pjn.2009.1465.1471

[33] Ling, S., Tai, M., Lee Goh, K., Taib, S.M., Rampal, S. and Mahadeva, S. (2010) Anthropometric, Biochemical and Clinical Assessment of Malnutrition in Malaysian Patients with Advanced Cirrhosis. Nutrition Journal, 9, 27. http://dx.doi.org/10.1186/1475-2891-9-27

[34] Attia, K.A., Ackoundou-N'guessan, K.C., N’dri-yoman, A.T., Mahassadi, A.K., et al. (2008) Child-Pugh-Turcott versus Meld Score for Predicting Survival in a Retrospective Cohort of Black African Cirrhotic Patients. World Journal of Gastroenterology, 14, 286-291. http://dx.doi.org/10.3748/wjg.14.286

[35] Kamani, L., Mumtaz, K., Ahmed, U.S., Ali, A.W. and Jaffery, W. (2008) Outcomes in Culture Positive and Culture Negative Ascitic Fluid Infection in Patients with Viral Cirrhosis: Cohort Study. BMC Gastroenterology, 8, 59. http://dx.doi.org/10.1186/1471-230X-8-59

[36] Iqbal, S., Iman, U.N., Aslam, N. and Rahman, S.U. (2005) Incidence of Spontaneous Bacterial Peritonitis in Liver Cirrhosis, Causative Organisms and Antibiotic Sensitivity. Journal of Postgraduate Medical Institute, 84, 614-618.

[37] Navasa, M., Rimola, A. and Rodés, J. (1997) Bacterial Infections in Liver Disease. Seminars in Liver Disease, 17, 323333. http://dx.doi.org/10.1055/s-2007-1007209

[38] Cruz, R.R., Tanajura, D., Almeida, D., Cruz, M. and Paraná, R. (2006) Urinary Tract Infection in Non-Hospitalized Patients with Cirrhosis and No Symptoms of Urinary Tract Infection: A Case Series Study. The Brazilian Journal of Infectious Diseases, 10, 380-383. http://dx.doi.org/10.1590/S1413-86702006000600004

[39] Levy, M., Dromer, F., Brion, N., Leturdu, F. and Carbon, C. (1988) Community-Acquired Pneumonia. Importance of Initial Noninvasive Bacteriologic and Radiographic Investigations. Chest, 93, 43-48. http://dx.doi.org/10.1378/chest.93.1.43

[40] Shakil, A.O., Korula, J., Kanel, G.C., Murray, N.G.B. and Reynolds, T.B. (1996) Diagnostic Features of Tuberculous Peritonitis in the Absence and Presence of Chronic Liver Disease: A Case Control Study. American Journal of Medicine, 100, 179-185. http://dx.doi.org/10.1016/S0002-9343(97)89456-9

[41] Al Muneef, M., Memish, Z., Al Mahmoud, S., Al Sadoon, S., Bannatyne, R. and Khan, Y. (2001) Tuberculosis in the Belly: A Review of Forty-Six Cases Involving the Gastrointestinal Tract and Peritoneum. Scandinavian Journal of Gastroenterology, 5, 528-532. http://dx.doi.org/10.1080/00365520117945

[42] Baijal, R., Praveenkumar, H.R., Amarapurkar, D.N., Nagaraj, K. and Jain, M. (2010) Prevalence of Tuberculosis in Patients with Cirrhosis of Liver in Western India. Tropical Doctor, 40, 163-164. http://dx.doi.org/10.1258/td.2010.090463

[43] Yoo, C.G., Kim, Y.W., Han, S.K., Shim, Y.S. and Yim, J.J. (2007) Characteristics of Tuberculosis in Patients with Liver Cirrhosis. Respirology, 12, 401-405. http://dx.doi.org/10.1111/j.1440-1843.2007.01069.x

[44] Thulstrup, A.M., Mølle, I., Svendsen, N. and Sørensen, H.T. (2000) Incidence and Prognosis of Tuberculosis in Patients with Cirrhosis of the Liver. A Danish Nationwide Population Based Study. Epidemiology and Infection, 124, 221-225. http://dx.doi.org/10.1017/S0950268899003593 
[45] Liu, B.M., Chung, K.J., Chen, C.H., Kung, C.T., Ko, S.F., Liu, P.P. and Chang, H.W. (2008) Risk Factors for the Outcome of Cirrhotic Patients with Soft Tissue Infections. Journal of Clinical Gastroenterology, 42, 312-316. http://dx.doi.org/10.1097/MCG.0b013e31802dbde8

[46] Rongey, C., Lim, N.H. and Runyon, B.A. (2008) Cellulitis in Patients with Cirrhosis and Edema: An Under-Recognized Complication Currently More Common than Spontaneous Bacterial Peritonitis. The Open Gastroenterology Journal, 2, 24-27. http://dx.doi.org/10.2174/1874259900802010024

[47] Horowitz, Y., Sperber, A.D. and Almong, Y. (2004) Gram Negative Cellulites Complication Cirrhosis. Mayo Clinic Proceedings, 79, 247-250. http://dx.doi.org/10.4065/79.2.247

[48] Mohan, P., Ramu, B., Bashkar, E. and Venkataraman, J. (2011) Prevalence and Risk Factors for Bacterial Skin Infections and Mortality in Cirrhosis. Annals of Hepatology, 10, 15-20.

[49] Kuo, C.M., Kuo, C.H. and Changchien, C.S. (2001) Liver Abscess in Patients with Cirrhosis of the Liver: A 12-Year Experience. Journal of Gastroenterology, 36, 552-556. http://dx.doi.org/10.1007/s005350170058

[50] Chang, W.N., Lu, C.H., Chang, C.S. and Huang, C.R. (2003) Community Acquired Spontaneous Bacterial Meningitis in Patients with Alcoholic Liver Disease. Journal of the Formosan Medical Association, 102, 653-655.

[51] Su, C.M., Chang, W.N., Tsai, N.W., Huang, C.R., Wang, H.C. and Lu, C.H. (2010) Clinical Features and Outcome of Community-Acquired Bacterial Meningitis in Adult Patients with Liver Cirrhosis. American Journal of the Medical Sciences, 340, 452-456. http://dx.doi.org/10.1097/MAJ.0b013e3181ee988d

[52] Bajaj, J.S., Zadvornova, Y., Heuman, D.M., Hafeezullah, M., Hoffmann, R.G., Sanyal, A.J. and Saeian, K. (2009) Associations of Proton Pump Inhibitor Therapy with Spontaneous Bacterial Peritonitis in Cirrhotic Patients with Ascites. American Journal of Gastroenterology, 104, 1130-1134. http://dx.doi.org/10.1038/ajg.2009.80

[53] Choi, E.J., Lee, H.J., Kim, K.O., Lee, S.H., Eun, J.R., Jang, B.I. and Kim, T.N. (2011) Association between Acid Suppressive Therapy and Spontaneous Bacterial Peritonitis in Cirrhotic Patients with Ascites. Scandinavian Journal of Gastroenterology, 46, 616-620. http://dx.doi.org/10.3109/00365521.2011.551891

[54] Kondrup, J. (2006) Nutrition in End Stage Liver Disease. Best Practice \& Research Clinical Gastroenterology, 20, 547560. http://dx.doi.org/10.1016/j.bpg.2006.02.001

[55] Campillo, B., Richardet, J.P. and Bories, P.N. (2006) Validation of Body Mass Index for the Diagnosis of Malnutrition in Patients with Liver Cirrhosis. Gastroentérologie Clinique et Biologique, 30, 1137-1143. http://dx.doi.org/10.1016/s0399-8320(06)73491-1

[56] Gunsar, F., Riamondo, M.L., Jones, S., Terreni, N., Wong, C., Patch, D., Sabin, C. and Burroughs, A.K. (2006) Nutritional Status and Prognosis in Cirrhotic Patients. Alimentary Pharmacology \& Therapeutics, 24, 563-572. http://dx.doi.org/10.1111/j.1365-2036.2006.03003.x

[57] Merli, M., Lucidi, C., Giannelli, V., Giusto, M., Riggio, O., Falcone, M., Ridola, L., Attili, A.F. and Venditti, M. (2010) Cirrhotic Patients Are at Risk for Health Care-Associated Bacterial Infections. Clinical Gastroenterology and Hepatology, 8, 979-985. http://dx.doi.org/10.1016/j.cgh.2010.06.024 